\title{
Democracy and Infomediaries
}

\author{
Mark Latham*
}

We can improve our political and economic systems by redesigning our use of informational intermediaries (infomediaries). Examples of infomediaries are political parties, the news media, proxy voting advisory firms and auditors. An infomediary's source of funding influences the information it produces - "follow the money". Political campaign finance reform is one approach to redesigning our infomediary systems. This paper proposes another approach: starting a few companies with a new corporate bylaw structure designed to enhance management accountability to shareowners. Shareowners would vote annually to hire an infomediary (paid with corporate funds) to advise them on proxy voting. If this system proves effective, it can spread to existing corporations and then to the political arena.

Keywords: Corporate governance, monitoring, proxy voting, democracy, infomediaries, informational intermediaries, free-rider problem, rational apathy, management accountability, corporate social responsibility

\section{Introduction}

D emocracy is inefficient, because voting is a collective decision process. Your one vote has so little effect on you personally that unless you are public-spirited, you have almost no incentive to spend time studying the issues so as to vote more intelligently. ${ }^{1}$ Economists call this a "free-rider" problem: if you spend time on voting, the community benefits without paying you, thus getting a free ride on your efforts. As a result, we spend less time and effort on intelligent voting than is socially optimal, and the quality of our democratic decisions suffers. Our monitoring of elected representatives' performance is similarly hampered by the free-rider problem. The resulting inefficiencies, and special interest power structures that result, are addressed by a broad political science literature exemplified by Lohmann (1998) and Zywicki (1999).

Because of this difficulty in decision-making by large groups of people (and the dangers of giving a few people power over everyone else), political and economic systems have evolved toward privatisation. The basic prin- ciples of private property and voluntary exchange tend to give decision-making authority to the minimum number of people primarily affected by each decision. Ideally, each individual or family decides how much to work, what to buy and how to use their possessions, subject to voluntary exchange by the counterparties involved.

But decision-making by large groups persists in two settings: civic and corporate. Civic democracy governs decisions with broad social effects and no practical means for voluntary individual participation: national defence, the legal system, natural monopolies in infrastructure, support for the poor, etc. Ongoing debate over such issues as education vouchers will determine which functions are included in this civic sphere. Corporations jointly owned by many investors have arisen in the private sphere in businesses where the inefficiencies of group decision-making are outweighed by the benefits of economies of scale and risk-sharing.

Voting by citizens and voting by corporate shareowners have several features in common. Day-to-day executive decisions of
* Address for correspondence: 268 Bush Street \#3934, San Francisco, CA 94104, USA. Tel \& Fax: +1 (415) 680 1521. Email: mlatham@corpmon.com 
governments and of corporations are delegated to elected representatives and their appointees. (Sometimes a few prominent issues are decided directly by the voters.) The voters hold ultimate power, but the free-rider problem limits their effective exercise of that power. Selection and monitoring of those elected is not as careful as one would hope.

Yet civic and corporate voting differ in certain aspects significant to this article. Corporate shareowners generally agree on the primary goal for the joint enterprise (profit), while political goals vary widely in civic societies. Corporate board elections are rarely contested - usually just one nominee per open seat; civic elections are usually contested. Shareowners get one vote per share; citizens get one vote per person. Investors can easily diversify as well as shift their shareholdings across hundreds of corporations, whereas citizens would have to uproot their lives to change which societies (city, state, nation) they belong to. Perhaps as a result of these features, individuals pay even less attention to how they vote as shareowners than to how they vote as citizens.

Thus our greatest power structures - governments and corporations - are built on the shaky foundation of voting, with its free-rider weakness. We are rightly wary of any force that could break the tenuous link between voting and the collective interest. One such force is the buying and selling of votes, which we prohibit and prevent by ensuring confidentiality of voting. Influencing votes by means of information is considered legitimate, but since money can influence information, this too could undermine the link between voting and the collective interest. This paper explores ways of designing and funding our information systems so as to enhance rather than undermine the quality of democratic decisions.

The information business has huge economies of scale. So not just for voting, but any need for information tends to be served by intermediaries (infomediaries) who create, gather and organise it for a mass market. The resulting cost saving is especially important for voting, however, given the lack of individual incentive to spend money or effort to vote better.

Section 2 below lists infomediaries that influence voting for public office and shareowner voting in corporations, as well as those that influence individual decisions about investing, consuming and working. General principles are then proposed for designing effective infomediary systems, to minimise bias while funding sufficient quality. Changing established power structures is an uphill battle however, so Section 3 shows how to implement these principles in the corporate bylaws of a startup company. The key feature is to use corporate funds to pay for an independent proxy-voting advisor chosen by annual shareowner vote. Section 4 describes how this new power structure design can spread if it proves effective. By reducing agency costs, it should be possible to both increase profit and advance other social goals. Voters have the ultimate power, so once they see what works, they can implement it in existing corporations and in governments. Section 5 concludes the paper.

\section{Design principles for infomediary systems}

Table 1 lists prominent types of infomediaries in the USA. While this paper focuses on voting, infomediaries we use for individual decision-making are also shown for comparison.

A corporation's managers have different interests from its shareowners, so the term "corporate interests" is ambiguous. When listing corporate funds as a potential source of influence on an infomediary, the table distinguishes whether managers or shareowners are directing the funds. Usually it is managers, denoted "Corp Mgt".

The recent McCain-Feingold campaign finance reform bill in the US senate illustrates several points relevant here: American democracy's infomediary systems are seen as important, in need of change, and difficult but not impossible to change. This section will propose some desirable features for infomediary systems that can plausibly be expected to enhance democratic decisions and improve accountability of elected representatives. ${ }^{2}$ Obstacles to change will then be examined, and a way around them suggested.

\section{Source of funds}

"Follow the money." This is the most obvious potential cause of bias for an infomediary. Whoever controls funding may manipulate the information provided, to influence elections for their private gain at public expense. The McCain-Feingold Bill tried to limit corporate contributions to political campaigns for this reason.

A conflicted funding source does not necessarily undermine credibility, however. The power of reputation (discussed below) can effectively counteract this bias, for example with credit rating agencies. 


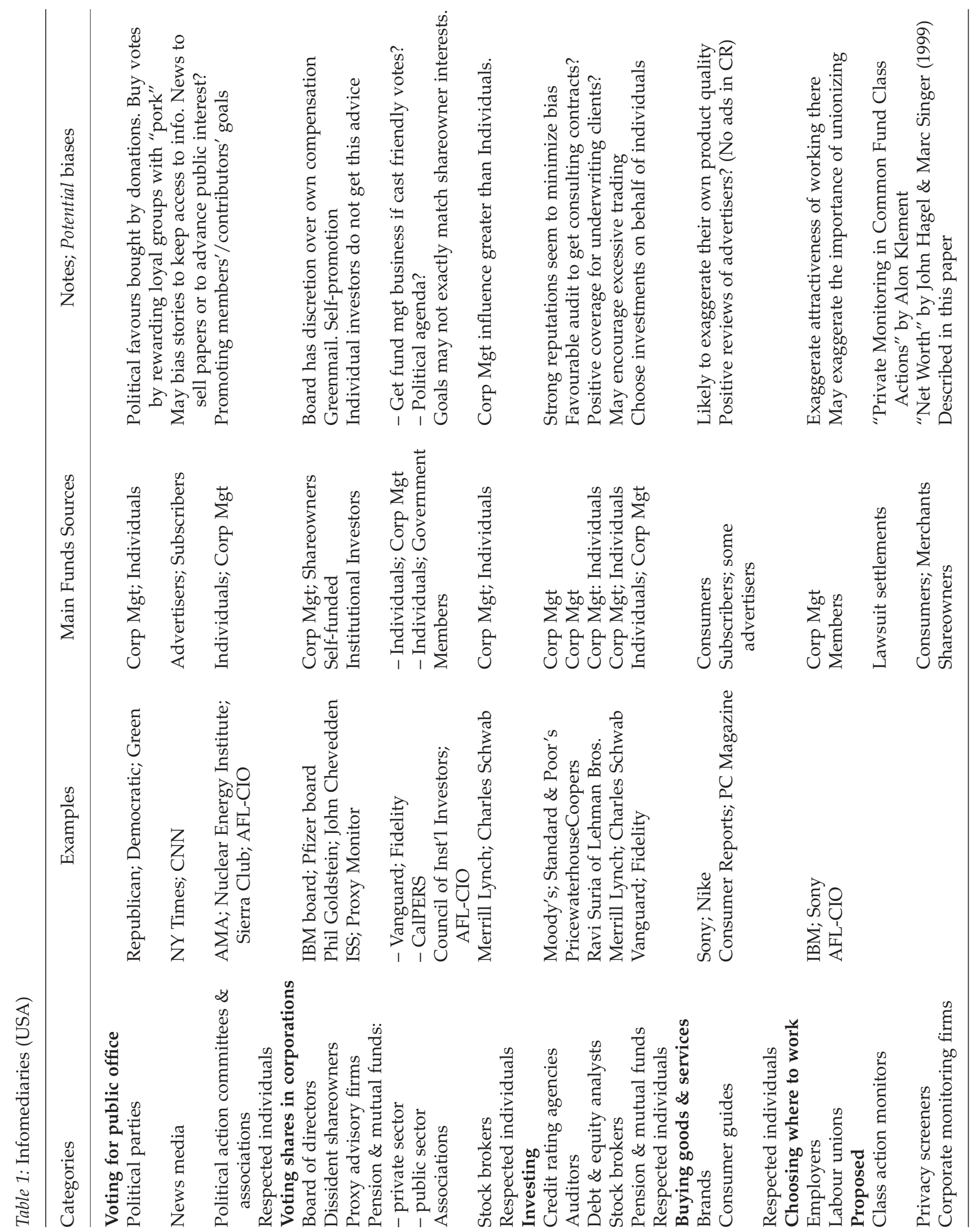


Nonetheless, if we are designing a better system, clearly one desirable feature would be for funding to be controlled by someone with interests aligned to those of the information customers (voters). One possible way to achieve this would be for the customers themselves to control the infomediary's funding, as do the subscribers to Consumer Reports. At the same time, the source and motivation of funding should preferably not be hampered by the free-rider problem: those controlling the funds should have the incentive to balance the total social costs and benefits of the information.

\section{Number of competing infomediaries}

Customers tend to be best served when infomediaries are numerous enough to enhance competition, yet few enough to permit public awareness of their reputations. The characteristics of the particular information market being served will determine both the optimal trade-off between these two opposing factors, as well as the actual market-equilibrium number of infomediaries (which may not be optimal).

Consider credit rating agencies, such as Standard \& Poor's. Strikingly, although they are paid by the corporations whose debt they are rating (so that management can choose which rating agency to hire), the agencies' need to maintain reputation seems strong enough to prevent bias. Perhaps because there are only two or three major agencies, management seems unable to "buy" a better credit rating.

Contrast this with the number of corporate boards of directors who give advice on how to vote proxies. Many institutional investors subscribe to research from independent proxy advisory firms, and/or maintain their own proxy analysis staffs, so do not depend on directors' advice. But individual shareowners typically have convenient access only to the directors' recommendations. In terms of competition, each board has a monopoly on advising individuals who vote shares of that one corporation; in terms of reputation, with over 9000 listed firms each with its own board, there are too many boards (and directors) for the financial community to efficiently determine their reputations. This is the worst of both worlds - too few and too many at the same time! The problem is further compounded by the board's monopoly of nominating new director candidates whose names will appear in the company-paid proxy ballot.

One design strategy for achieving an efficient number of infomediaries is to ensure ease of entry for new competitors. The difficulty for newcomers to build widespread reputations will automatically keep their number from becoming excessive.

\section{Longevity}

The longer an infomediary expects to remain in business, the greater its incentive to invest in reputation. Most infomediary systems depend on reputation to mitigate conflicts of interest, with the idea that the truth comes out eventually - "you can't fool all the people all the time". The similar condition in Coffee (2001) is that the gatekeeper be a "repeat player", having a strong incentive to invest in reputation for the sake of future business. Thus for example, an organisation like the New York Times or PriceWaterhouse Coopers can build a reputation that lasts longer than any one individual's career. "Chainsaw $\mathrm{Al}^{\text {" }}$ Dunlap had a reputation for enhancing shareowner value when he was CEO of various companies, until his disastrous farewell performance at Sunbeam. ${ }^{3}$ We can design better infomediary systems based on organisational reputation than on individual reputation.

\section{“Thinness"}

Who watches the watchers? How can we expect to benefit by adding a layer of monitoring when those monitors will themselves have conflicts of interest? Whatever is the top layer of monitoring, it will ultimately be up to the voters (or consumers) to determine whether the monitors are faithful and effective. Because this ultimate assessment is difficult, hampered by the free-rider problem, we can limit the potential for corruption by minimising the scope and functions of the top monitors. We have only their general reputations to keep them honest.

Many existing monitoring systems embody this principle. Corporate boards oversee management but do not manage, and most directors are paid far less than the CEO. Auditors face legal limits on providing other consulting services to clients..$^{5}$ Likewise in Klement's (2001) proposal for lawsuit monitors, it is emphasised that "[c]ompared to litigating a class action, monitoring is much cheaper and easier to perform". Indeed, the whole concept of an infomediary or gatekeeper is one of thinness: information only, a guide to action rather than performing an active function. Thinness limits the concentration of power, like the system of checks and balances in the US government. 
It is all very well to design a new infomediary system for improving our democratic power structures, but any plan to actually implement a new design will face daunting obstacles. The power structures we have are the product of a long evolutionary process they are there for a reason (or many reasons). Many intelligent and public-spirited participants have tried to guide this evolution toward structures that work for the public benefit. Regardless of whether they have succeeded however, any attempt to fundamentally change the power structure must expect opposition from those with the most power now. This is almost a "Catch-22", a contradiction that blocks change; but it also means that the eventual breakthrough of change can be dramatic, even revolutionary.

The easiest time to implement change is when we are creating a new power structure, like the US constitution when the country was formed. By contrast, for example, while it might now be beneficial to allow preferential voting in presidential elections, both major parties - Republican and Democratic - are likely to oppose it because it would facilitate the growth of a third party. ${ }^{6}$ Opportunities are rare for designing new political democracies from scratch. But new corporate democracies are created every week - the shareowner communities of startup companies. Corporate laws in the US allow considerable variation in writing the charter and bylaws that define each company's power structure.

Section 3 below proposes adding a new infomediary to the standard US corporate power structure, to strengthen shareowner democracy so that managers will better serve the shareowners' interests. Section 4 describes how this system, if proven effective, can spread to existing corporations and then to political democracies as well.

\section{Proposed system for shareowner voting}

Section 2 above listed the infomediaries influencing corporate shareowner voting, including boards, dissident shareowners, proxy advisory firms, and pension and mutual funds. Along with various regulations, these form the monitoring mechanisms that encourage boards of directors to serve the interests of their electors, the shareowners. However, boards and the CEOs who chair them seem still to have substantial conflicts of interest: tendencies to overpay the $\mathrm{CEO}$, to delay replacing underperforming $\mathrm{CEOs}$ and directors, to conceal poor performance, to discourage potential acquirers of the firm, and more -
Monks and Minow (1996) provide a survey, as does the recent Enron debacle. This section will describe a proposal for reducing these agency costs for the typical publicly traded American firm with no majority shareowner. ${ }^{7}$

Selling the stock of a poorly managed company provides a market-based check on abuse of CEO power, because a depressed stock price can invite a hostile takeover to threaten the CEO's position. However, the sizable premium a raider must pay and the legal obstacles to takeovers allow management considerable leeway before this "market for corporate control" can correct governance problems. Unlike a sale of open-end mutual fund shares, the sale of corporate stock does not remove assets from management's control. All the unhappy seller does is pass the stock along to a buyer who must then suffer the same management abuses and will discount the stock price accordingly. If there were a low-cost way to improve corporate governance, a prospective seller would benefit by voting for its implementation, then selling at a presumably enhanced price.

A broad and varied corporate governance literature has proposed and debated numerous possible ways to reduce the agency costs of manager-shareowner conflicts. Hatherly (1995), Monks and Minow (1996) and Hawley and Williams (2000) discuss many of these. One prominent design strategy is based on the political concept of checks and balances with a separation of powers (Persson et al., 1996; Diermeier and Myerson, 1999). In the corporate context, institutions proposed to divide or counterbalance the power of a CEO-dominated board of directors include the separation of CEO and board chair roles, increasing the number of non-executive directors on the board and its key committees (audit; compensation; nominating), and creating a second board or panel with distinctly defined functions (Hatherly 1995; Guthrie and Turnbull 1995; Dallas 1997; Turnbull 2000). Some countries such as Germany legally require a second board.

When designing such a countervailing institution, greater loyalty to shareowner interests may be achievable by reducing the free-rider or rational voter apathy problem described in the Introduction above. Thus Baums and von Randow (1995) proposed a system of professional voting agents in the German institutional context, and Latham (1998, 1999a, 2000) proposed several designs for the American context, the simplest of which is a proxy advisory firm (PAF) similar to those existing now, which would advise shareowners on how to vote their stock. However, to solve the free-rider problem hampering existing PAFs, it 
would be paid by each corporation it covers, rather than by only those shareowners subscribing to PAF research. To ensure loyalty to shareowners, the PAF hired to cover a firm would be selected by shareowner vote, thus satisfying condition (a) in Section 2 above. ${ }^{8}$ All shareowners of each covered firm would receive the voting advice, in the company proxy, via the Web, and/or by automated telephone system. Competition among PAFs would be enhanced by the direct competition for shareowner votes at each firm, and by the ease of entry for new PAFs, who need only cover a few firms rather than all 9000-odd listed companies for the existing PAF business model.

While the Internet has accelerated the growth and availability of cheap information that shareowners can use to vote more intelligently, there still seems much room for improvement for the purpose of disciplining corporate management. Critical analysis and assessment of director performance, stock option plans, and merger and recapitalisation proposals for example, are too costly to provide if shareowners can free-ride and receive that information for next to nothing. And the time it takes to process the mass of cheaply available information is itself a cost that a professional infomediary can help reduce.

A company-paid PAF bears some resemblance to a board of directors: both are paid with corporate funds, and selected by shareowner vote. But some of Section 2's conditions indicate that a company-paid PAF would be more loyal to shareowner interests. There are now only two PAFs in the USA. ${ }^{9}$ While ease of entry may increase this number to 10 or 20, it would remain low enough for shareowners to easily learn about their reputations in the financial press. The minimal amount of time required to do this greatly reduces the shareowner voting free-rider problem (but does not quite eliminate it). By contrast, a system of competitive director elections is impractical because there are thousands of potential directors - too many for the financial community to efficiently judge. Furthermore, the greater longevity of a PAF compared to an individual director makes it more of a "repeat player", again enhancing its incentive to build reputation. This may not completely eliminate management influence on the PAF's voting recommendations, but it would give the PAF a stronger incentive to resist such influence than any infomediary has in our existing corporate governance system.

Section 2's last condition, "thinness", may become problematic for a company-paid PAF. If this design is successful in creating a wellfunded infomediary with a better reputation than the board of directors for serving share- owner interests, then shareowners may want to expand its functions. Setting the agenda is more fundamental than advising on the vote. If you trust the PAF more than the board to tell you which director to vote for and whether to approve the stock option plan, then why let the board nominate the director candidates and choose the stock option plan? The PAF could perform those functions in consultation with the board, hiring outside consultants if necessary (as boards do). Choosing the firm's auditor is likewise a sensitive decision in which the board probably has conflicts of interest, so may be better overseen by a more trusted independent agent. Such an agent can also provide a safer audience for whistleblowers to report management misconduct.

This expanded infomediary is called a "Corporate Monitoring Firm" (CMF) in Latham (1998). At what point would an excessive concentration of power outweigh the benefits of adding functions to this trusted agent? The optimal trade-off may be determined by experience. One remedy may be for the CMF to outsource such key functions as executive search and compensation consulting, thus staying "thin" by minimising its own fee.

Because a company-paid PAF would reduce the power of the board of directors, one can not expect a board to voluntarily institute this proposed change. Instead, in 1999 I organised a shareowner proposal campaign to raise awareness of the idea and build support for its implementation. We have submitted the proposal at 13 companies, and succeeded at getting it into the proxy for shareowner vote at five of these. The boards opposed it in all cases, giving arguments and recommendations for shareowners to vote against it. So far, votes in favour have ranged from 2.4 per cent to 17.8 per cent. It takes time to understand a new idea, and to counteract the expected Catch-22 opposition from vested interests. ${ }^{10}$

It should be easier to implement this proposal at a startup company than at a publicly traded firm. A startup has fewer shareowners that need to be convinced. The enhanced protection of shareowner interests provided by a company-paid PAF should merit a higher share price when the startup makes an initial public offering (IPO). However, it requires faith or some special motivation to be the first to try a new unproven design. Investors may not pay a premium right away for a supposed enhancement that they do not yet understand. The company-paid PAF business needs multiple clients for investment in reputation to be most effective, although new entrants would probably have reputations in related work, such as investor-paid proxy advising. 
Another possible avenue for initiating a company-paid PAF system is the Internet business model of offering some information for free, building demand, then finding a way to charge for it later. In a way, this has already begun. Since 1999, the California Public Employees Retirement System (CalPERS) has been posting some of its proxy voting decisions on the Web two weeks before each annual meeting voting deadline. This gives individual shareowners free professional independent guidance on how to vote their stock, for the first time. A growing number of other institutional investors have started posting their decisions too. ${ }^{11}$ Because the incentive for individuals to vote is so weak, there seems to be no rush to take advantage of this free information. But if and when Internet stock brokers like Charles Schwab build online proxy voting into their websites, ${ }^{12}$ it would be easy to give shareowners the option to see CalPERS' decision next to the board's recommendation for each proxy issue, and to create a button saying "Vote this proxy the way CalPERS voted theirs". This would build effective demand for "free" voting advice, creating a need for something like the company-pay system to improve the quality and coverage of that advice.

On the other hand, this new shareownerchosen infomediary design may be tried first outside the USA, in countries where economic development has suffered from poor corporate governance, such as Japan, Russia, or countries of Eastern Europe. Building institutions to emulate the necessary components of the successful American model has proven difficult, so a simple and different approach like the company-paid PAF may be worth trying.

\section{From corporate governance to politics}

If the reasoning presented here is valid and a company-paid PAF would benefit shareowners, where might this development lead? Such a fundamental change to corporate power structures could have a broad impact. However, it is hard to predict the path of a complex interactive group learning and system evolution process. The basic economic principle of rational self-interest in decisionmaking is one guide, but the mathematics of voting in large groups greatly weakens this incentive. The infomediary system in place at one stage may or may not provide effective unbiased support for the voting decisions needed to improve the infomediary system itself.
The case for a shareowner-chosen companypaid PAF is plausible enough that it is likely to be tried somewhere. It will take at least several companies and several years to begin to determine whether the experiment is successful. Although profitability and stock market returns are crucial measures of success, other signs of a healthy governance system should be apparent long before superior returns become statistically significant, given the considerable noise from random effects on profit. CEOs and directors of companies with this new infomediary in place will feel different, will design different shapes of compensation plans, and will approach their own succession planning differently from counterparts in conventional firms. (Similarly, the potential for antilock braking systems on cars to save lives can be seen from their superior controlled braking performance, without waiting years for confirmation by accident statistics.)

The primary benefit should be increased stock returns resulting from lower agency costs when management's conflicts of interest are reduced by making them more accountable to shareowners. If the first company-paid PAFs are seen as beneficial, shareowners of some firms may choose to expand the PAF to include such functions as nominating directors, choosing the auditor, and designing compensation plans (as mentioned in Section 3), becoming what I call corporate monitoring firms (CMFs). For simplicity, I will include company-paid PAFs under the blanket term $\mathrm{CMF}$ for the remainder of this paper.

Rational self-interest of shareowners should lead to adoption of CMFs at more and more existing firms, once they see the new system working elsewhere. Even if the change is opposed by the board of directors, a majority of the shareowners can force the issue by electing a dissident board slate if necessary.

Corporate governance theory and practice have paid considerable attention to aligning the incentives of managers with shareowners by making the managers shareowners, typically via large grants of stock options. While this helps align the incentive to increase profit, it unfortunately exacerbates a misalignment of incentives regarding the firm's "externalities" - impacts on the world that are neither market-priced nor effectively regulated. These include environmental impacts, exercise of market power, creation and management of "intellectual property", investigative journalism and political influence by lobbying and campaign contributions, to name a few. All are issues of tension between public and private interests. The CMF system offers a competitive private market alternative to the adversarial 
political machinations that currently determine policy on such issues.

Consider the following illustration: Suppose you are the sole owner and operator of a factory. You live in the same building as your factory, located miles from any other human being. (Apparently you are a survivalist.) You are about to buy a new machine which will run all night every night, and have two models to choose from. One is quiet, and the other is noisy but costs US\$1 less per night to run. The noisy one would keep you from sleeping, so you decide your sleep is worth much more than US\$1, and buy the quiet model. No one would argue with your decision, although viewed simplistically you are not maximising profit. Machine noise would not be an externality here, since you would only be inflicting it on yourself - it is internalised, fully taken into account when you decide.

Next, suppose instead that the factory belongs to 100 equal shareowners, who all happen to live close enough to the factory for the noise to disturb them. Depending on the cost differential, they might all prefer that their firm buy the more expensive, quieter machine. But two problems can arise if the firm's management tries to take these preferences into account: factionalism among the shareowners, and difficulty of measuring management performance. If some owners live farther away or are deaf, they may prefer the noisier cheaper machine. You can't please everyone. And management could try to excuse low profits by saying they have been enhancing the shareowners' environment (ecological, social etc.) by purchasing quiet machines and by various other means that benefit the community but are hard to measure. To avoid these two problems, we often have our governments regulate environmental impacts, like this noise, which becomes an externality if corporate management is supposed to give precedence to financial goals.

But assigning the responsibility to governments merely relocates these problems rather than solving them. Factionalism and lack of accountability are hallmarks of politics. Regulation of the wide range of public-private conflicts is notoriously inefficient, often a tug-of-war among various private donors and political factions.

The CMF system was originally designed to increase corporate profits by making management more accountable to shareowners. But once such an infomediary has built its reputation for pursuing shareowners' financial interests, shareowners may be willing to trust a CMF to give some consideration to externalities also. CMFs would then have to respond to such shareowners' wishes when competing for votes. ${ }^{13}$ The reason why shareowners have a self-interest in considering externalities is explained in the next paragraph below. They may trust a CMF to respond to this interest for the same reason they would trust a CMF to respond to their financial interests: the CMF's reputation for serving their clients so as to win more business. It would be more difficult, however, for the investment community to assess reputations for this more subtle task of balancing externalities with profits, so such a development would take time.

Both the CEO and shareowners want their firm to make more profit. However, we can expect shareowners to take a more public-spirited view of externalities because they are far more diversified (invested in many other companies) than the typical CEO. ${ }^{14}$ Most shares of major US firms are held by pension and mutual funds, which typically diversify their investments widely across companies. Indeed, many are index funds, owning stock of 500 or more of the largest firms. By contrast, CEOs tend to be very undiversified, with not only their careers but also their large stock and option holdings tied to the fortunes of one firm. Shareowners are thus more likely to vote for CMFs that give greater weight to the public interest than CEOs do now, resulting in voluntary reduction of pollution, less abuse of (and quest for) monopoly power, more generous corporate management of "intellectual property", more investigative journalism for public benefit, less special-interest lobbying, and so on.

Corporate donations to political campaigns are a particularly striking and important example of this manager-shareowner conflict of interests. Again to start with a simplified illustration, suppose you are managing a firm, and an encumbent politician offers you this deal: donate US\$1 million to his re-election campaign, and receive an immediate US\$2 million tax break. Imagine for now that this is legal, ethical and (just to make sure) will remain secret anyway. Then to maximise profit, you should accept the deal. Now instead suppose you are an indexed investor, invested in all publicly traded US firms, including this one. Would you want your CEO to accept the deal? I maintain you would not, because the US\$2 million tax break is going into one of your pockets but coming out of another. You are playing a zero-sum game (negative-sum actually) with yourself. The US $\$ 2$ million lost tax revenue must be made up by taxing other firms (which you own), taxing individuals (you again) or cutting government services which you presumably consume. 
Realistically, campaign contributions are unlikely to have such an explicit quidpro-quo, but the effect seems much the same: contributions are seen as increasing the chance of government largesse toward the donor.

"'Everyone knows big checks get noticed,' says Edward A. Kangas, chair of the accounting firm Deloitte Touche. For many business leaders, he says, the 'soft-money shakedown... looks like extortion to us.' John H. Bryan, chief executive of Sara Lee calls the fundraising racket 'legalized bribery,' and says, 'Everyone knows the system is absurd.' Both men are leaders in the Committee for Economic Development, a business-backed group that favors banning soft money..." (p. 1) $)^{15}$

Recent empirical work by Gupta and Swenson (2001) confirms that political contributions by firms and managers are positively associated with firm tax benefits at stake, and that this association is stronger when managers' compensation is significantly tied to firm performance. A CMF system offers the tantalising prospect of gaining more democratic and public-interested control over corporate donations, the biggest pool of funds influencing our political system. ${ }^{16}$ We can accomplish this by merely exerting our property rights (and voting rights) as shareowners.

Some externalities such as pollution can in principle be controlled by appropriate levels of "green taxes", thus making corporate profit maximisation socially optimal. But it seems fundamentally impossible to implement such a financial adjustment to account for corporate political influence, which may be the most important externality of all.

CMFs would be paid and trusted to analyse and take positions on balancing private gain with the public interest. These are political issues. It is only a small step further to start endorsing candidates for public office, and opposing politicians who practice negativesum shakedowns. This new force could help break the political gridlock that often seems to prevent implementation of win-win solutions. CMFs could become too powerful though, in violation of Section 2's thinness condition, so perhaps separate organisations could be created for the political sphere, funded from tax revenue and chosen by public vote. In other words, if CMFs prove successful for enhancing shareowner voting, we could use that as a model for public financing of political infomediaries.

Multinational corporations have increasingly international shareowner communities. CMFs would therefore be effectively international organisations in terms of their funding and source of voting support. They would rep- resent democratic communities with common interests transcending national boundaries, thus becoming a force for global co-operation on private and public issues.

\section{Conclusions}

A new system of monitoring intermediaries can improve the governance of large corporations. Shareowners would vote to choose among competing "corporate monitoring firms" (CMFs), which would be paid from corporate funds. CMFs would advise shareowners on how to vote their shares, and might also nominate directors and negotiate compensation plans. This arrangement would give corporate management greater incentive to serve shareowner interests. CMFs would be more accountable to shareowners than directors are now because, being less numerous than directors, their reputations are much easier for the financial community to determine.

This system can be expected to increase stock returns by improved control of the compensation and succession of CEOs and directors, greater attention to shareowner value in mergers and acquisitions, and reducing other agency costs of the shareowner-manager relationship. It can also help balance profit maximisation with broader social goals that benefit shareowners, especially by discouraging the negative-sum special-interest games played by CEOs and politicians at public expense. The CMF could thus become a force for improving our political system domestically and internationally.

This CMF proposal has not yet been implemented at any corporation. While there would be some risk involved in trying it for the first time, the cost would be tiny compared to the huge potential public benefit if it is successful, since it could then be applied to so many other corporations. It is therefore in the interests of shareowners to support this innovation.

\section{Acknowledgements}

I gratefully acknowledge helpful comments from Mark Rubinstein, Robert C. Merton, Richard Homonoff, Jim McRitchie and two anonymous referees.

\section{Notes}

1. This paper focuses on large communities of 1000 or more people. These problems are of course less severe in smaller communities. Paying people to vote (or fining them if they do 
not, as in Australia) overcomes the free-rider cost of taking the trouble to vote, but unfortunately provides no incentive to spend the time to become informed and vote intelligently.

2. These features overlap substantially with the three conditions outlined by Coffee (2001) for enhancing the effectiveness of gatekeepers such as auditors, based on the original analysis of Kraakman (1986).

3. See "Dangerous Games: Did 'Chainsaw $\mathrm{Al}^{\prime}$ Dunlap manufacture Sunbeam's earnings last year?" in Barron's, 8 June 1998.

4. I borrowed this term from the "thin client" concept in computer networks. See, for example, http://webopedia.internet.com/ TERM/t/thin_client.html

5. See "Shining light on the markets" in The Economist, 28 October 2000. SEC chairman Levitt argued essentially that auditor thinness would benefit investors.

6. Preferential voting would enable each voter to rank the candidates; for example, Nader first (Green Party), Gore second (Democratic Party), Bush third (Republican Party). When the votes are counted, if it becomes clear that Nader has insufficient votes to win, all Nader-first votes become votes for the second choice (Gore for this voter), thus eliminating the problem of vote-splitting where the third candidate hurts the ideologically closer major party. More at http://www.corpmon.com/Voting Reform.htm

7. Latham (1999b) examined ways to extend this proposal to firms with a majority shareowner. Although many American firms have what La Porta et al. (1999) call a "controlling" shareowner, they define this as someone with over 20 per cent of the shares. That may be sufficient for effective control of a firm in the current institutional setting, where the free-rider problem prevents other shareowners from voting in a co-ordinated fashion. However, the proposal outlined here can provide the focus needed for smaller shareowners to aggregate their power, and out-vote a large shareowner as long as that holding is less than 50 per cent of the shares.

8. The system could be designed to permit funding more than one PAF to cover a company. Shareowners wishing to minimise time spent on voting could use their same ranking of PAF reputation when choosing which advice to take as when choosing which PAF(s) to fund. See also http: / / www.corpmon. com/ProposalFAQ.htm for answers to frequently asked questions about this proposal.

9. The two American PAFs are Institutional Shareholder Services (http:/ /iss.cda.com) and Investor Responsibility Research Center (http://www.irrc.org). Note that in the case of auditors, selection by the board of directors gave auditors the incentive to build reputations for pleasing the board, not for pleasing shareowners.

10. Details on the proposal campaign are at http://www.corpmon.com and http://www. corpmon.com/ProposalSubmissions.htm
11. Links to these institutions are at http:/ / www.corpmon.com/Vote.htm

12. One online broker has been doing this since the year 2000: http:/ / www.foliofn.com

13. This point was made in Latham (1998) and expanded in Hawley and Williams (2000) who emphasise the growing role of public pension funds as monitors of management and defenders of the public interest. It does, however, raise the issue of conflicting interests among different subgroups of shareowners. CMFs could respond first by giving different voting advice to different shareowners, and then more helpfully by seeking new corporate policies adjusted so as to benefit a broader majority of owners.

14. The potential for balancing financial and nonfinancial goals may make CMFs a valuable tool for improving management of nonprofits also.

15. Quoted from Democracy South, 26 March 2001, at http://www.all4democracy.org/ softmoney/Softmoneyhitshome.htm. See also http:/ / www.ced.org/docs/releasepoll.doc.

16. Investing some social security funds in stocks could make corporate monitoring even more democratic, if beneficiaries start voting their shares.

\section{References}

Baums, T. and von Randow, P. (1995) Shareholder Voting and Corporate Governance: The German Experience and a New Approach. In M. Aoki and H. Kim (eds), Corporate Governance in Transitional Economies. Washington, DC: The World Bank, 435-458.

Coffee, J. C. Jr. (2001) The Acquiescent Gatekeeper: Reputational Intermediaries, Auditor Independence and the Governance of Accounting. Columbia Law School, The Center for Law and Economic Studies; Working Paper No. 191 (May).

Dallas, L. L. (1997) Proposals for Reform of Corporate Boards of Directors: The Dual Board and Board Ombudsperson, Washington \& Lee Law Review, 54, 91-147.

Diermeier, D. and Myerson, R. B. (1999) Bicameralism and its Consequences for the Internal Organization of Legislatures, American Economic Review, 89, 1182-1196.

Gupta, S. and Swenson, C. W. (2001) Rent-Seeking by Agents of the Firm. Working paper available at http://papers.ssrn.com/paper.taf?abstract_ $\mathrm{id}=278445$ (April).

Guthrie, J. and Turnbull, S. (1995) Audit Committees: Is There a Role for Corporate Senates and/or Stakeholder Councils? Corporate Governance: An International Review, 3, 78-89.

Hagel, J. III and Singer, M. (1999) Net Worth. Boston, MA: Harvard Business School Press.

Hatherly, D. J. (1995) The case for the shareholder panel in the UK, The European Accounting Review, 4, 535-553.

Hawley, J. P. and Williams, A. T. (2000) The Rise of Fiduciary Capitalism. Philadelphia, PA: University of Pennsylvania Press. 
Klement, A. (2001) Who Should Guard the Guardians? A New Approach for Monitoring Class Action Lawyers, The Review of Litigation, 21, 25-82.

Kraakman, R. (1986) Gatekeepers: The Anatomy of a Third-Party Enforcement Strategy, Journal of Law, Economics, and Organization, 2, 53-104.

La Porta, R., Lopez-de-Silanes, R. F. and Schleifer, A. (1999) Corporate Ownership Around the World, Journal of Finance, 54, 471-517.

Latham, M. (1998) Corporate Monitoring: New Shareholder Power Tool, Financial Analysts Journal 54, 9-15.

Latham, M. (1999a) The Corporate Monitoring Firm, Corporate Governance: An International Review, 7, 12-20.

Latham, M. (1999b) Collective Action for Dispersed Shareowners, Corporate Governance International (September); CollectiveAction.htm

Latham, M. (2000) The Internet Will Drive Corporate Monitoring, Corporate Governance International, 3, 4-11;

http:/ / www.corpmon.com/IntCM.htm

Lohmann, S. (1998) An Information Rationale for the Power of Special Interests, American Political Science Review, 92, 809-827.

Monks, R. A. G. and Minow, N. (1996) Watching the Watchers. Malden, MA: Blackwell.
Persson, T., Roland, G. and Tabellini, G. (1996) Separation of Powers and Accountability: Towards a Formal Approach to Comparative Politics. Centre for Economic Policy Research, Discussion Paper No. 1475 (September); http://papers.ssrn.com/ sol3/papers.cfm?abstract_id $=4856$

Turnbull, S. (2000) Corporate Charters with Competitive Advantages, St. Johns Law Review, 74, 101-159.

Zywicki, T. (1999) Environmental Externalities and Political Externalities: The Political Economy of Environmental Regulation and Reform, Tulane Law Review, 73, 845-921.

Mark Latham received his $\mathrm{PhD}$ in Finance from MIT in 1984, supervised by Fischer Black and Robert C. Merton. He was Assistant Professor of Finance at the University of California, Berkeley, until 1989. From 1989 to 1995 he worked for the New York investment banks Salomon Brothers and Merrill Lynch, mainly on derivatives arbitrage trading in Tokyo equity markets. Since 1996 he has been doing independent research on corporate governance, founding the Corporate Monitoring Project - website www.corpmon.com.

"It's not just companies that need to up their game on pay. Many institutions spend too much time complaining and not enough time analysing. Executive pay is a complex issue, and investors can't rely on a tick box template." Editorial, International Corporate Governance, June 2002. 